\title{
Migracje kobiet - strategie odzyskiwania głosu i ciała w twórczości literackiej Polek mieszkających w Wielkiej Brytanii i Irlandii
}

Anna Kronenberg

TEKSTY DRUGIE 2016, NR 3, S. 98-115

DOI: $10.18318 /$ td.2016.3.6

Użzwając literatury, nie pragnę wtaczyó się wn nieskończony proces odczytan tekstu, tylko w nieskonczony proces poznawania i tworzenia społeczeństwa. ${ }^{1}$

A rtykuł prezentuje wnioski z badań nad twórczością literacką Polek mieszkających w Wielkiej Brytanii i Irlandii (37 powieści, 17 fragmentów dzienników, twórczość 23 poetek), która powstała po 2004 roku. Zwraca uwagę bardzo duża aktywność literacka i społeczno-kulturalna Polek na emigracji. Większość zarówno opublikowanych utworów literackich, jak i inicjatyw społecznych jest dziełem kobiet ${ }^{2}$. Co więcej, w większości przypadków Polki podejmują takie działania dopiero na emigracji, dlatego w ich twórczości literackiej przeważają debiuty, a wśród liderek - „debiutantki”.

1 K. Dunin Czytając Polskę, W.A.B., Warszawa 2004, s. 26.

2 "Uderzającą cechą [...] jest przewaga liczbowa prac nadesłanych przez kobiety (około 2/3)", zob. B. Gołębiowski Emigranci czy Europejczycy?, w: Wyfrunęli. Nowa emigracja o sobie, red. W.T. Czartoryska, Stopka, Łomża 2011, s. 326.
Anna Kronenberg - dr, współpracuje z UŁ (Ośrodek Naukowo-Badawczy Problematyki Kobiet) i IBL PAN. Ostatnie publikacje związane z tematyką gender: Emigracjai twórczość emigracyjna Polek - od ewolucji spotecznych do literackich, "Civitas Hominibus" 1(10)/2015, Polityka reprezentacji: zwiq̨zki ideologii, whadzy i płci, "Civitas Hominibus", 1/2014; Geopoetyka. Zwiqzki ilteratury iśrodowiska (2015) Kontakt: akronenberg@uni.lodz.pl 
Uzupełnienie badań nad zjawiskiem migracji, szczególnie tych najnowszych, o perspektywę kobiet mieszkających w Wielkiej Brytanii i Irlandii, o bogactwo i różnorodność ich głosów w twórczości literackiej, uważam za niezwykle ważne ${ }^{3}$. Wybrany przedział czasowy, lata 2004-2014, stanowi dobrą okazję dla wstępnych podsumowań twórczości literackiej pierwszej dekady od przystąpienia Polski do Unii Europejskiej i związanych z tym masowych migracji.

\section{Polityczność twórczości kobiet stanowi jej ważny kapitał"}

Jak pisze Inga Iwasiów: „obecność kobiet na scenie publicznej jest polityczna"5. Autorki, pisząc o doświadczeniu bycia kobietą w Polsce i na emigracji, poruszają wiele tematów społecznych, tym samym je upolityczniając. Dlatego adekwatną metodologią badania tej twórczości jest rozpatrywanie tekstów literackich jako tekstów kultury, jako: „elementu procesów komunikacyjnych, dyskursywnych praktyk, uwikłanych w stosunki władzy politycznej, ekonomicznej i kulturowej". Taką metodologię, na przecięciu socjologii i antropologii literatury oraz badań kulturowych i gender, zdefiniowali i praktykują: m.in. Maria Janion7, Inga Iwasiów, Kinga Dunin ${ }^{8}$, Przemysław Czapliński', Agnieszka Mrozik ${ }^{10}$, Agnieszka Graff'11. Ważne, aby badania nad twórczością

3 Zob. np. Poetyka migracji. Doświadczenie granic w literaturze polskiej przełomu XX i XXI wieku, red. P. Czapliński, R. Makarska, Wydawnictwo UŚ, Katowice 2013; Narracje migracyine w literaturze polskiejXXiXXI wieku, red. H. Gosk, Universitas, Kraków 2012; Migracje kobiet. Perspektywa wielowymiarowa, red. K. Slany, Wydawnictwo UI, Kraków 2008.

4 I. Iwasiów Granice. Polityczność prozy i dyskursu kobiet po 1989 roku, Wydawnictwo Naukowe US, Szczecin 2013, s. 13.

5 Tamże, S. 15.

6 A. Mrozik Akuszerki transformacii, Wydawnictwo IBL PAN, Warszawa 2013, s. 10.

7 Zob. np. M. Janion Kobiety iduch inności, Sic!, Warszawa 1996; tejże Niesamowita słowiańszczyzna: fantazmaty literatury, Wydawnictwo Literackie, Kraków 2006.

8 K. Dunin Czytaig̨ Polskę.

9 Zob. m.in. P. Czapliński Resztki nowoczesności. Dwa studia o literaturze i życiu, Wydawnictwo Literackie, Kraków 2011; tegoż Historia, narracja, sprawczość, w: Historia-dziś. Teoretyczne problemy wiedzyo przeszłości, red. E. Domańska, Universitas, Kraków 2014، s. 283-302.

A. Mrozik Akuszerki transformacij. Zob. także Polityka literatury. Przewodnik Krytyki Politycznej, red. K. Dunin, Wydawnictwo Krytyki Politycznej, Warszawa 2009.

11 A. Graff Świat bez kobiet. Płeć w polskim życiu publicznym., W.A.B., Warszawa 2001. 
kobiet uwzględniały kwestie związane z płcią: "genderowa perspektywa jest dla literatury pisanej przez kobiety ostatnich dwóch dekad szczególnie istotna"12.

Wśród ważnych problemów społecznych jest dyskryminacja na rynku pracy w Polsce, zwłaszcza w sfeminizowanych zawodach:

byłam bez przerwy bombardowana informacjami o strajkach moich koleżanek pielęgniarek, Ich dramatyczny [...] protest (głodówki) pozostał bez echa; zostały one poniżone i zignorowane przez polskie władze. Jakże kontrastowało to z wysoką pozycją zawodową, społeczną i materialną pielęgniarek w Wielkiej Brytanii [...] przesądziło o moim wyjeździe do Walii. ${ }^{13}$

Kolejne autorki wskazują inne, rzadko podejmowane w literaturze zagadnienie - feminizację biedy: „te wszystkie spracowane, starsze, ubrane na ciemno kobiety, stojące w kolejkach do aptecznej kasy z odliczoną kwotą"14. Z kolei Łucja Fice prezentuje wykluczenie, z jakim zmagają się „kobiety 50+" na rynku pracy. Jej bohaterka, Gabriela Mrozińska, zdobyła kwalifikacje opiekunki i pracę w Anglii. Los Gabrieli ukazuje zjawiska, z którymi często borykają się emigrantki: samotność, kryzys małżeński, rozluźnienie kontaktów z dziećmi i poczucie winy ${ }^{15}$.

W twórczości tej znajdziemy także wątek wykluczenia kobiet w średnim wieku z życia społecznego i towarzyskiego:

w Polsce zaczynać wszystko w wieku 49 lat? Toż to wstyd! Kto mnie zatrudni? Jak ja się z Robertem pokażę? Tutaj nic nikogo nie dziwi. [...] Jestem tu pełnoprawnym członkiem społeczeństwa, a nie starą babą. ${ }^{16}$

12 U. Chowaniec Smutek jest podszewka świata "Zadra" 2012 nr 3-4 (52-53), s. 88.

13 A. Szafran Porawracać, w: Wyfrunęli..., s. 276-277.

14 J. Nowak Opowieść emigracyina, Novae Res, Gdynia 2010, s. 56.

15 Historie takie można znaleźć w badanej twórczości często, np. w powieściach Łucji Fice i w dziennikach z dwóch antologii: Wyfrunęli oraz Na końcu świata napisane. Autoportret współczesnejpolskiejemigracji, red. E. Spadzińska-Żak, Videograf II, Katowice 2008.

16 J. Nowak Opowieść emigracyina, s. 56 
Autorki, przez dobór tematów, protestują także przeciwko łamaniu praw pracowniczych oraz wyzyskowi, z którymi spotykają się emigrantki ${ }^{17}$. Z kolei Łucja Fice ${ }^{18}$ w swojej twórczości przełamuje tabu związane z samotnością i umieraniem pacjentów w domach opieki. Tworzy narrację o godności grup wykluczonych: osobach terminalnie chorych i ich opiekunkach. Domaga się dla nich miejsca w społeczeństwie.

Badaną twórczość emigracyjną można zaliczyć do literatury popularnej. Jednocześnie wykracza ona poza tę kategorię. Te próby łączenia literatury rozrywkowej z zaangażowaną stanowią według mnie cechę wyróżniającą twórczość emigracyjną kobiet na tle literatury krajowej. Nie jest to częste połączenie. Popularne pisarki mieszkające w Polsce rzadko podejmują ważne tematy społeczne. Możemy wskazać nieliczne przykłady: Hanna Samson, Olga Tokarczuk, Joanna Bator, Grażyna Plebanek, Marta Dzido, Manuela Gretkowska. Większość z nich mieszkała i pracowała za granicą.

Autorki szerokiego nurtu literatury popularnej odżegnują się od ruchu na rzecz praw kobiet: „ponowoczesny wysyp produkcji «literatury kobiecej» ponownie zakrywa, unieszkodliwia kobiecą podmiotowość jako podmiotowość buntowniczki"19. Wyjątkiem jest Katarzyna Grochola ${ }^{20}$. Dlatego polityczność prozy emigracyjnej stanowi jej ważny kapitał. Polityczne jest także opisywanie doświadczeń bycia kobietą w przestrzeni publicznej i prywatnej oraz kobiecej cielesności, które można nazwać strategiami odzyskiwania ciała i głosu przez Polki.

\section{Kobiece praktyki autobiograficzne}

Badana twórczość jest w większości autobiograficzna. Sidonie Smith i Julia Watson, podsumowując badania nad podmiotowością w kobiecych

17 Zob. np. D. Parys-White Emigrantka zwyboru, Videograf II, Chorzów 2008; M. Zimny-Louis Ślady hamowania, Wydawnictwo Replika, Poznań 2011, A.M. Bakalar Madame Mephisto, Stork Press, London 2012; A. Obirek Wtoski koszmar, w: Wyfrunęli, s. 121-123; M. Orzeł Dublin. Moja polska karma, Skrzat, Kraków 2007; B. Kamińska Dziecko dwóch matek, w: Wyfrunęli, s. 251-264; K. Tubylewicz Rówieśniczki, W.A.B., Warszawa 2014; J. Nowak Opowieść emigracyina.

Ł. Fice Przeznaczenie; tejże Wyspa Starców, WFW, Warszawa 2013; tejże Opiekunka, Sonar, Gorzów 2012. 
praktykach autobiograficznych, podkreślają, że trzy czynniki są w niej kluczowe: doświadczenie, podmiotowość i seksualnośćn ${ }^{21}$.

Zagadnienie dochodzenia do głosu i wypowiadania kobiecej podmiotowości jest badane w teorii feministycznej od lat 8o. XX wieku na przykładzie codziennego, osobistego pisarstwa kobiet. Najnowsza literatura emigracyjna także daje bogaty i różnorodny materiał w tym zakresie. Za Anną E. Goldman interesuje mnie: „w jaki sposób narratorki sytuują się pomiędzy presją ze strony «ja» i ze strony «my» $i$ «manewrują pomiędzy autobiograficznymi polityczno-kulturowymi tekstami» oraz dążą do samouobecnienia poprzez «reprezentowanie» zbiorowości"22. Cielesność jest waźnym tematem badań nad tekstami kobiet. Autorki twórczości emigracyjnej także badają w jaki sposób kobieca cielesność została wpisana w praktyki społeczne. Ciało staje się przestrzenią, na której spotykają się płeć kulturowa i płeć biologiczna.

W ramach tworzenia teorii na temat kobiecej autobiografii Sidonie Smith i Julia Watson wymieniają 12 kierunków badań autobiograficznych. Wybrałam cztery, które uznałam za najbardziej adekwatne dla twórczości emigracyjnej.

\section{Relacyjność}

Bohaterki twórczości emigracyjnej często tworzą alternatywne, poszerzone wspólnoty kobiet, np. wynajmujących wspólnie dom przyjaciółek, matek, córek. W Emigrantce z wyboru kobiety wynajmują pokoje u pani Jadwigi: „była nam matką, ojcem, bratem, siostrą - wszystkim. Była kochana"23. Przyjaźń i obopólne wsparcie połączyły także Klarę Miodowską i jej pracodawczynię, panią Wacławę, która podarowała dziewczynie część majątku, by umoźliwić jej niezaleźność ekonomiczną na emigracji²4. Bliską, choć bardziej złożoną więź stworzyła bohaterka Imigracji Kai Malanowskiej ze swoją promotorką, profesor Emily:

21 S. Smith, J. Watson Wprowadzenie: koncepcja podmiotowości w kobiecych praktykach autobiograficznych, przeł. A. Grzemska, w: Teorie wywrotowe. Antologia przekładów, red. A. Gajewska, Wydawnictwo Poznańskie, Poznań 2012, s. 33.

22 A.E. Goldmanza S. S. Smith, I. Watson Wprowadzenie, s. 77.

23 D. Parys-White Emigrantka z wyboru.

24 J. Nowak Opowieść emigracyina. 
[...] cztery lata później cisnęłam w nią książką.

- Ty głupia dziwko! - wywrzeszczałam.

A ona stała w drzwiach gabinetu [...] i uśmiechała się do mnie.

- Moja krew - powiedziała. - Chyba cię adoptuję. Nigdy nikomu nie pozwól się zdominować. Rozumiesz? Nikomu. Jesteś kobietą, a kobiety ceni się, tylko jeżeli są silne. ${ }^{25}$

Katarzynie Przybylskiej rodzinę zastępuje krąg kobiet, które pełnią rolę grupy wsparcia ${ }^{26}$. Kobiecą wspólnotę sąsiedzką przedstawiają powieści Anny Łajkowskiej ${ }^{27}$, a Alicja Szafran opisuje grupę polskich pielęgniarek i przyjaciólek pracujących $w$ Waliii ${ }^{28}$. Z kolei Emigracja uczuc ${ }^{29}$ ukazuje konsekwencje emigracji zarobkowej mężczyzn z perspektywy ich żon (uzależnienia i zdrady mężów, ich brak więzi z dziećmi, rozpad rodzin). Czasem problemy nasilają się, gdy żona z dziećmi dołącza do męża ${ }^{30}$. Twórczość literacka kobiet ukazuje wysokie koszty społeczne emigracji, dlatego mogłaby być ważnym głosem w debacie publicznej.

Kolejnym kręgiem, w którym bohaterki uzyskują wsparcie, są ich matki, babcie, siostry, przyjaciółki, które zostały w kraju: „babcia [...] karmiła mnie gołąbkami. Ewka [...] sprawdza czy nie zapomniałam [...] ostatniej Zadry. Mama wpakowała mi [...] pękatą apteczkę" ${ }^{\prime \prime}$. Krewne troszczą się nie tylko o sprawy by towe, ale i potrzeby intelektualne, czego symbolem jest „ostatnia «Zadra»" - magazyn feministyczny ${ }^{32}$. To także wyraz światopoglądu bohaterki oraz zapowiedź tematów, które autorka poruszy.

Autorki podejmują temat związków rodzinnych i społecznych „po kądzieli". Wypełniają tym samym jedno z najważniejszych zadań, jakie stoi przed

25 K. Malanowska Imigracje, Wydawnictwo Krytyki Politycznej, Warszawa 2011, s. 129.

G. Brzezińska Irlandzki koktajl, Wydawnictwo Bliskie, Warszawa 2010, s. 282.

A. Łajkowska Pensjonat na wrzosowisku, Wydawnictwo Damidos, Katowice 212; tejże Miłość na wrzosowisku, Damidos, Katowice 2012; tejże Cienie na wrzosowisku, Damidos, Katowice 2013.

A. Szafran Pora wracać.

A. Bednarska Emigracja uczuć, Replika, Zakrzewo 2012. "Sebastian pił prawie codziennie [...] zaczął się awanturować. [...] wyprowadziłam się z dziećmi [...] to, czemu poświęciłam kilkanaście lat życia, okazało się wielką pomyłką". B. Kamińska Dziecko dwóch matek, s. 262. 
pisarstwem kobiet: „konieczne jest odrestaurowanie filaru, którego brakuje naszej kulturze: relacji matki z córką, szacunku dla kobiecego słowa"33. Także dla Belli Brodzki „zniewalającą figurą, prześladującą kobiece teksty autobiograficzne, jest właśnie figura utraconej matki"34. Pisarki polskie wypełniają tę białą plamę od lat 9o. XX wieku:

literatura kobieca [...] przemawia głosem córek: nie mają one i nie chcą mieć dla swoich matek zrozumienia ani litości. Uciszane przez dziesięciolecia, niewidoczne, stłamszone, dziś wychodzą z cienia, pragnąc wyrzucić z siebie całą nagromadzoną złość i ból. ${ }^{35}$

Więź z matką zostaje krytycznie zredefiniowana, a wraz z nią więź z polską tradycją, historią, narodem. Jako jedna z pierwszych pisała o tym Adrienne Rich: „oczywiście matka służy interesom patriarchatu: uosabia religię, społeczne sumienie i nacjonalizm. Zinstytucjonalizowane macierzyństwo ożywia i podtrzymuje wszystkie inne instytucje" ${ }^{36}$. Relacje bohaterek z matkami stanowią obszerny temat w twórczości emigracyjnej: od miłości i tęsknoty do całkowitego odrzucenia matki. Na przykład Gabriela Mrozińska utrzymuje bliską więź ze zmarłą matką³. Dla Barbary tęsknota za bliskim, codziennym kontaktem z matką, pogłębia poczucie osamotnienia na emigracji38. W dzienniku Anety Loski matka i córka dzielą los emigrantek, stworzyły w domu nieoficjalne centrum pomocy Polakom: „przez dwa lata w naszym domu mieszkało prawie sto osób. Z większością z nich były problemy" ${ }^{39}$. Z kolei w powieści Madame Mephisto matka Magdy symbolizuje to,

33 K. Szczuka Kopciuszek, Frankenstein i inne. Feminizm wobec mitu, Wydawnictwo eFKa, Warszawa 2001 , S. 25.

S. Smith, J. Watson Wprowadzenie..., s. 61.

A. Mrozik Akuszerki transformacji, s. 197.

36 A. Rich Zrodzone z kobiety. Macierzyństwo jako doświadczenie i instytucia, przeł. J. Mizielińska, Sic!, Warszawa 2000, s. 88.

37 Postać zmarłej matki pojawia się w ważnych momentach życia bohaterki, by doradzać i podnosić na duchu - zarówno we śnie, jak i na jawie. Parapsychologiczne zdolności Gabrysi Mrozińskiej ujawniają się także wobec krewnego, którego odnalazła w Walii. Bohaterka ta potrafi też interpretować sny i jest obdarzona dobrą intuicją, co sprawia, że koleżanki z pracy zwracają się do niej po pomoc. Zob. Ł. Fice Przeznaczenie.

38 A. Łajkowska Pensjonat na wrzosowisku, tejże Miłość na wrzosowisku, tejże Cienie na wrzosowisku.

39 A. Loska Uciekłam na mojq wyspę, s. 57. 
przed czym bohaterka uciekła: bezrefleksyjną religijność i przywiązanie do tradycji. Magda tak wyjaśnia matce powody emigracji: „zawsze wydaje ci się, że wiesz, czego chcę, ale ja chcę czegoś innego. [...] Dławiłam się [...] w tym kraju"40.

Powieść Magdaleny Zimy-Louis ukazuje różnorodne relacje matek z córkami: Danuta porzuciła nastoletnią córkę: „pojechałam za Karolem [...] jego picie było ważniejsze niż Justynka, a tego sobie nie wybaczę nigdy"41. Marlena jest przywiązana do swojej matki, natomiast jej siostra Iza traktuje matkę lekceważąco i zaprzyjaźnia się z wieloletnią kochanką ojca. Matki ukazane są jako osoby podporządkowane, podatne na manipulację religijną i pełne uprzedzeń. Natalia: „połowę emerytury wysyła do Radia Maryja i piętnastego każdego miesiąca przechodzi na ziemniaki z kefirem!"42. Z kolei matka Izy i Marleny:

twierdzi, że Murzyni wydzielają przykre zapachy [...] uważa, że Pan Bóg nie stworzył upośledzonych umysłowo [...] to jest jednak trochę obrzydliwe być karłem [...] Rumunów, Ukraińców i Arabów w ogóle nie powinno się wpuszczać do naszego kraju. Nie miała żadnej, ale to żadnej litości dla osób homoseksualnych i niewierzących. ${ }^{43}$

Konflikty te podszyte są bólem córek, których matki nie potrafią zaakceptować ich aspiracji zawodowych i wyborów życiowych. Co więcej, matki pełnią czasem także funkcję dyscyplinującą, stojąc na straży tradycji patriarchalnej: „niech ci Bóg dobrego chłopa wreszcie ześle, bo to wstyd przed ludźmi, żebym ja jeszcze wnuków nie miała. Jeszcze kto pomyśli, że ty jesteś ta... no, jak jej tam... lesbójka"44 - mówi matka Klary Miodowskiej.Z kolei narratorka dziennika Małgorzaty Białeckiej uświadamia sobie, że presja matki stała się jej wewnętrznym głosem: „dziewczynki są miłe [...] Dziewczynki wychodzą za mąż i rodzą dzieci - zrobiłabyś coś z tym wreszcie!"45. Presja dotyczy także sukcesów zawodowych. Matka Marty, bohaterki Oddalonych,

\footnotetext{
40 A.M. Bakalar Madame Mephisto, Stork Press, London 2012 [przeł. - A.K.].

44 J. Nowak Opowieść emigracyjna, s. 143.

M. Zimny-Louis Ślady hamowania, s. 279

Tamże, s. 47.

Tamże, s. 139.

M. Białecka Odczarować Anglię, w: Wyfrunęli, s. 128.
} 
mówi: „niewielu powiodło się w Anglii tak jak tobie [...] Wszystkim opowiadam, jaki odniosłaś sukces" ${ }^{46}$ - w momencie, gdy córka jest bezrobotna i zagrożona bezdomnością. Marta podtrzymuje iluzję matki, ponieważ wie, że nie otrzyma od niej wsparcia w momencie porażki. Na tym tle wartościowym przykładem przepracowywania więzi matki i córki jest powieść Marty Zaraski:

- I nie chcę kariery - mówię szybko, niecierpliwie. - nie chcę realizować twoich marzeń, mamo [...] Nie, nie przeproszę. Nie, nie jest mi wstyd. [...] Nie chcę być tylko perfekcyjną córką [...] chociaż raz mnie wysłuchaj. [...]. Nie, nie będę grzeczna. Ale to nie znaczy, że... - Słyszę jej oddech.

- Mamo... Kocham cię... - mówię i wiem, że ona też chce powiedzieć, kocham cię, córeczko. ${ }^{47}$

Proces rekonstruowania relacji matek i córek może być, jak pisze Agnieszka Mrozik: „zalążkiem feministycznej rewolucji, po której nastanie nowy, bardziej przyjazny kobietom porządek" ${ }^{48}$. W twórczości emigracyjnej odnajdziemy bardzo wiele przykładów sojuszy, przyjaźni i współpracy międzypokoleniowej kobiet. Takie narracje stwarzają możliwości budowania podobnych więzi w rzeczywistości.

\section{Związek między tworzeniem tożsamości narodowej a narracją auto- biograficzną}

„Społeczności ludzkie tworzą [...] narracje, które opowiadają o podstawach ich egzystencji jako odrębnych zbiorowości, a autobiografia [...] funkcjonuje jako potężne narzędzie takiej narracji" ${ }^{\prime 4}$. Dlatego warto przyjrzeć się najnowszej literaturze emigracyjnej kobiet także pod kątem reprodukcji i redefinicji tożsamości narodowej. Narodowe dyskursy zbudowane są na kategoriach „innego" i „obcego”, do których to grup tradycyjnie należały w kulturze kobiety. Dlatego ich twórczość daje nam szansę na usłyszenie głosu z obrzeży.

\footnotetext{
46 P. Courtney Oddaleni, przeł. I. Kraśko, Świat Książki, Warszawa 2009, s. 151.

47 M. Zaraska Zawieszeni, s. 339.

48 A. Mrozik Akuszerkitransformacji, s. 198.

49 S. Smith, J. Watson Wprowadzenie..., s. 85.
} 
Dystans ten zwiększa dodatkowo emigracja $\mathrm{a}^{50}$. Dlatego też: „odczytania autobiograficznych tekstów kobiecych muszą zostać odniesione do różnych [...] mitów narodowej toźsamości i jak przedstawiają siebie jako narodowe/lub nienarodowe podmioty" ${ }^{\text {"11 }}$. Oto przykład reprodukowania narodowego dyskursu, który podkreśla atrakcyjność seksualną Polek: „często wyśmiewały się z Julką z braku smaku walijskich kobiet, które nie umiały tak dbać o siebie jak Polki"52. Krytycznej redefinicji tego stereotypowego wizerunku Polek dokonuje Magdalena Orzeł: „Irlandczycy jak i Polacy. Mają zgodną opinię. Polki są najpiękniejsze. [...] zawsze zadbane, zrobione"53. Narratorka zastanawia się: „jak nam, Polkom - zapracowanym, poniewieranym i poniżanym - udało się zbudować taki mit?" ${ }^{54}$. Dochodzi do wniosku, że służy on utrzymaniu męskiej władzy: „mimo że pochlebiają mi te męskie [...] umizgi, to wiem, co się za nimi kryje. Chcą ze mnie zrobić lalkę, rozkraczyć nogi i do woli manipulować, wydarłszy wcześniej wolną duszę" ${ }^{\prime 5}$. Zdarza się, że autorki bezrefleksyjnie powielają mit matki-Polki:

[Anglicy] szukali partnerek praktycznych, troskliwych, kochających, z matczynym, łagodnym sercem. [...] Dlatego Wschodnioeuropejki cieszyły się wielkim zainteresowaniem. [...] Nie opierały się przejęciu domowych obowiązków..$^{56}$

Z kolei powieść pt. Przebojowa Polka w Londynie ${ }^{57}$ do tego stopnia utrwala stereotypy na temat kobiet, że można ją nazwać elementem backlashu ${ }^{58}$.

50 "Okazał się zbawienny dla rozluźnienia tematyki narodowej w literaturze i otwarcia tejże na problemy [...] płci, seksualności, religii, wieku" -zob. A. Mrozik Akuszerki transformacii, s. 73.

Ł. Fice, Przeznaczenie, s. 136.

M. Orzeł, Dublin, s. 112.

54 Tamże.

55 Tamże, s. 113.

56 D. Parys-White Emigrantka z wyboru, s. 68.

57 A. Martynowska Przebojowa Polka w Londynie, Sonia Draga, Katowice 2012.

58 Backlash to walka konserwatywnych środowisk z ruchem na rzecz praw kobiet, toczona w mediach, polityce, kościele, popkulturze, która staje się częścią głównego nurtu kultury. Zob. S. Faludi Reakcja. Niewypowiedziana woina przeciw kobietom, przeł. A. Dzierzgowska, Czarna Owca, Warszawa 2012. 
Bohaterki, dla których ważna jest praca, zostają określone jako „flądry”, „, biurwy”, „harpie”, „karierowiczki”, „wyfiokowane lale”, „, naszpikowane botoksem zołzy", a ich aspiracje zawodowe są ośmieszane. Celem życia głównej bohaterki Beaty Martynek jest awans społeczny przez „upolowanie Anglika z rodowodem" i zostanie żoną-trofeum.

W twórczości emigracyjnej narracje, które dyskryminują i seksualizują kobiety, zdarzają się częściej w męskich utworach ${ }^{59}$. Być może jest to znak szerszego zjawiska społecznego - niechęci do Polek, które wyemigrowały, ponieważ odbierane są jako zbyt wyemancypowane. Przykładów dostarczają fora internetowe, na których Polki są atakowane i obrażane ${ }^{60}$.

Zdecydowana większość utworów charakteryzuje się krytycznym odczytywaniem polskiej narodowo-religijnej tradycji oraz świadomością relacji władzy (ekonomicznej, politycznej, symbolicznej), jakiej podlegają kobiety. Dlatego narracje te moźna określić jako postpatriarchalne. Autorki konstruują alternatywną kobiecą tożsamość - krytyczną, otwartą, świecką, wolną od nacjonalistycznej ideologii ${ }^{61}$ :

chciałam pokazać Magdę z jej bagażem polskości, a zarazem ją z tej polskości wyzwolić [...] Pochodzimy z kraju o mocnych, obezwładniających tradycjach - co się dzieje z człowiekiem, który chce sobie stworzyć zupełnie inne życie? ${ }^{62}$

Przykłady zmagania się z narodowymi mitami na temat Polek odnajdziemy u emigracyjnych autorek. Według Kazimiery Szczuki początek XXI wieku przyniósł wybitne osiągnięcia literackie na tym polu: Utwór o Matce i Ojczyźnie

59 Zob. P. Czerwiński Przebiegum życiae czyli kartonowa sieć, Świat Książki, Warszawa 2009; I. Bolec Zmartwychwstanie śmieciarza, w: Na końcu świata napisane, Videograf, Warszawa 2008, s. 66-107.

6o Joanna Bator wykorzystała wypowiedzi mężczyzn, które znajdowała na takich forach. J. Bator Ciemno, prawie noc, W.A.B., Warszawa 2013.

61 Zob. Marlena ze Śladów hamowania; Katarzyna Przybylska z Irlandzkiego koktajlu; bohaterka Imigracii: Ewa Werner z Zawieszonych; Aneta Loska, Małgorzata Białecka, Monika Kulczyk, Katarzyna Kozakowska, Alicja Szafran, Beata Kamińska z Wyfrunęli; bohaterki Emigrantkiz wyboru oraz Dublina; Barbara z powieści Anny Łajkowskiej, autorka Mojei podróźy przez życie; także twórczość Wioletty Grzegorzewskiej (np. Notatnik z wyspy, Wydawnictwo e-media, Częstochowa 2012). 
Bożeny Keff ${ }^{63}$, Między nami dobrzejest Doroty Masłowskiej ${ }^{64}$, Kieszonkowy atlas kobiet $^{65}$ Sylwii Chutnik. Autorki odpowiadają na pytanie: „gdzie jest miejsce dla kobiet w historii? Do kogo należy prawo konstruowania wspólnotowej opowieści?"66. Podobnie autorki emigracyjne, np. Maria Jarzębska:

Przygarbiona i samotna

Kiedy odpowiada "Trzeba zapytać ojca”

Na wszystkie moje pytania

Nie wiem, co począć

Chcę nią potrząsnąć

Odnaleźć ukryty zatrzask, aby ukazał

Kobietę

Która przez całą okupację

Przemierzała ulice Warszawy

Roznosząc w torbie tajne dokumenty

I nigdy nie dała się złapaćc7

Pisarki konstruują podmiotowość swoją oraz swoich matek i córek - jako obywatelek, które aktywnie współtworzą historię kraju. O tej trudności pisała Urszula Chowaniec: „córka jest przestrzenią kulturową niechcianą, choć notorycznie kolonizowaną i zagospodarowywaną"68.

W badanej twórczości autorki odchodzą od definiowania podmiotowości wedle narracji narodowej. Dyskurs narodowy został zastąpiony doświadczeniami nomadyczności, migracji, podróży: „emigracja jest kobietą, śmiało idzie do przodu, tęskni, kocha i nie boi się ryzyka!"69. Jednocześnie cechy pożądane dla Polki/Polski i emigrantki polskiej pozostają takie same, jak dla Matki-Polki: zaradność, pracowitość, samodzielność, odwaga. Może mamy do czynienia z tą samą presją kulturową, ale tym razem pod nową postacią - emigrantki? Narracja narodowa przekształciła się w liberalną, ale

\footnotetext{
63 B. Keff Utwór o Matce i Oiczyźnie, Ha!art, Kraków 2008.

64 D. Masłowska Między nami dobrze jest, Lampa i Iskra Boża, Warszawa 2008.

65 S. Chutnik Kieszonkowy atlas kobiet, Ha!art, Kraków 2008.

66 K. Szczuka Rewolucja jest kobietg, w: Polityka literatury. Przewodnik Krytyki Politycznej, s. 65.

67 M. Jarzębska Torba, w: FORUM POLEK, Grupa publikacyjna Forum, Londyn 1988, s. 118.

68 U. Chowaniec O córkach Matki Polki, „Zadra” $2011 \mathrm{nr} 3 / 4$ (48-49), s. 78.

69 G. Brzezińska Irlandzki koktajl, czwarta strona okładki.
} 
wymagania, jakie są stawiane przed kobietami i jakie kobiety same sobie stawiają - pozostają podobne. Tak zawężona definicja „kobiety-emigracji” pozostawia na marginesie część bohaterek i realnych kobiet, które nie są w stanie „śmiało iść do przodu” - z różnych powodów, bardziej wynikających z uwarunkowań kulturowych, społecznych, ekonomicznych, rodzinnych, mniej z ich własnej woli. W badanej twórczości ścierają się dwie narracje: dyskurs liberalny, właściwy współczesnej kulturze terapii, w którym podmiot jest wyizolowany z kontekstu społeczno-politycznego (bohaterka jako „kowal własnego losu") ${ }^{70}$ i dyskurs wrażliwy społecznie, uświadamiający mechanizmy indywidualnej, systemowej i symbolicznej dyskryminacji kobiet.

\section{Pamięć}

Badaczki zajmujące się autobiograficznymi praktykami kobiet interesuje także proces tworzenia i funkcjonowania pamięci - jednostkowej, zbiorowej, biochemicznej. Ważną częścią tych badań jest kierunek rozwijany od lat 9o. XX wieku, przywracający pamięć o przemilczanych doświadczeniach, „pisarski projekt przywracania i uprawomocniania wspomnień dotyczących molestowania seksualnego i psychicznej traumy - który usankcjonował wiele autobiograficznych narracji"71. Przykładem w Polsce są m.in. dzienniki Halszki Opfer ${ }^{72}$. Teoretyczki wskazują na bardzo ważną funkcję, jaką pełnią tego rodzaju świadectwa literackie - pozwalają one uzdrowić nie tylko jednostki, ale całe zbiorowości. Wskazują też na potencjał tych opowieści - ich bohaterki przechodzą drogę od wiktymizacji do witalizacji (uświadomienia sobie własnej siły, która pozwoliła przetrwać).

Pisarki emigracyjne teź przerywają milczenie na temat przemocy, jakiej doświadczają kobiety juz w dzieciństwie: np. Wioletta Grzegorzewska ${ }^{73}$, Grażyna Plebanek ${ }^{74}$, Magdalena Zimny-Louis ${ }^{75}$. Na emigracji dalej zmagają

70 Zob. np. D. Parys-White Emigrantkaz wyboru, s. 172.

71 S. Smith, J. Watson Wprowadzenie..., s. 86.

72 H. Opfer Kato-tata. Nie-pamiętnik, lacek Santorski E Co, Warszawa 2009; H. Opfer Monidło. Życie do Kato-tacie, Czarna Owca, Warszawa 2011; K. Surmiak-Domańska Mokradełko, Czarne, Wołowiec 2012.

73 W. Grzegorzewska Guguty, Czarne, Wołowiec 2014.

74 G. Plebanek Przystupa.

75 M. Zimny-Louis Ślady hamowania. 
się z przemocą. Na przykład Klara Miodowska ${ }^{76}$ przyjechała do Londynu do ciotki. Jej mąż Robert próbował ją zgwałcić, a ciotka to ją uznała za winną. Klara straciła mieszkanie i pomoc jedynej znajomej w obcym kraju osoby. To przylkład powtórnej wiktymizacji, z którym zmagają się ofiary przemocy. Gabriela Mrozińska jest poniżana i molestowana przez Marka - współpracownika i Polaka, a Klara przez szefa Rafała, także Polaka, który nie tylko domagał się seksu za awans, ale i tego, by pracowała dla niego jako prostytutka. Klara odmówiła i straciła pracę ${ }^{77}$ Z podobnymi propozycjami spotykała się Renata z Brzęczenia owczych dzwoneczków ${ }^{78}$.

Bohaterki nakłanianie są do pracy w seksbiznesie i zagrożone handlem kobietami: „teraz najwięcej ofert jest dla prostytutek, a oficjalnie dla masażystek i pań do towarzystwa"79; , takie młode dziewczyny wożą jak mięso! Dopóki się te małe nadają, a potem... E, szkoda gadać" ${ }^{\prime \prime}$. Dlaczego bohaterki literackie w tej twórczości tak często spotykają się z przemocą, molestowaniem i traktowane są jak potencjalne prostytutki? Status społeczny emigrantek jest niski, nie znają swoich praw, nie zdążyły zbudować siatki wspierających kontaktów - co czyni je łatwym celem mężczyzn, często o wyższej pozycji społecznej i mających władzę, oraz organizacji przestępczych. Jednak, jak pokazuje np. Natasha Walter, przyczyną są także procesy społeczne, które zachodzą w kulturze masowej i w mediach - zjawisko seksualizacji i uprzedmiotowienia kobiet, które wpływa negatywnie na ich pozycję zawodową ${ }^{81}$. Rynek pracy dla kobiet kurczy się, jednocześnie rozrasta się seksbiznes: „większość ofert pracy w gazetach i w Internecie dla kobiet w Polsce dotyczy prostytucji ${ }^{82}$; Polek pracowało u niego najwięcej, ale były też w ofercie Litwinki, Bułgarki i Białorusinki [...] Domowych burdeli w angielskich miastach było prawdziwe zatrzęsienie" ${ }^{\text {"83 }}$.

\footnotetext{
76 I. Nowak Opowieść emigracyina.

77 Tamże, s. 132-134.

78 R. Suchodolska Brzęczenie owczych dzwoneczków, w: Wyfrunęli.

79 P. Courtney Oddaleni, s. 178.

80 G. Plebanek Przystupa, s. 261.

81 N. Walter Żywe lalki. Powrót seksizmu, Czarna Owca, Warszawa 2012; S. Faludi Reakcja. Niewypowiedziana woina przeciw kobietom.

82 J. Nowak Opowieść emigracyjna, s. 16.

83 M. Zimny-Louis Kilka przypadków szczęśliwych, Prószyński i S-ka, Warszawa 2014, S. 168.
} 
Twórczość emigrantek ukazuje kolejny problem: Polki w sytuacji przemocy nie potrafią się sprzeciwić ani obronić. Wyjątkiem jest bohaterka powieści Joanny Zgadzaj, Magda ${ }^{84}$, która domaga się sprawiedliwości dla koleźanki $\mathrm{z}$ biura oraz równości w sytuacjach towarzyskich. Jej asertywna postawa naraża ją na ostracyzm i utratę pracy. Z jednej strony w narracjach emigracyjnych bohaterki, które nie godzą się na przemoc i dyskryminację, zostają ukarane (tracą pracę, mieszkanie, bywają obwiniane). Z drugiej - tak częste opisywanie w powieściach i dziennikach historii kobiet, które doświadczyły przemocy, najczęściej seksualnej, niezależnie od miejsca pracy, zawodu, klasy społecznej - możemy interpretować jako przerwanie milczenia i oznakę braku przyzwolenia na przemoc wobec kobiet. I jako jedną z najważniejszych strategii odzyskiwania głosu i ciała, początek procesu od wiktymizacji do witalizacji podmiotów kobiecych. Fakt, że wątki te pojawiają się tak często, dowodzi także, że emigracja jest dla Polek miejscem bezpiecznym, w którym mogą nie tylko zmierzyć się z bolesnymi doświadczeniami i opisać je, ale także upolitycznić, ukazując jako szerszy problem społeczny i systemowy, wynikający z kultury: „na wyspie poczułam się bezpieczniej jako kobieta i matka [...] jestem bardziej świadoma swoich praw"85.

\section{Teoria podróży}

Sidonie Smith i Julia Watson wskazują, że ważnym pytaniem jest: „w jaki sposób różne rodzaje mobilności wpływają na praktyki samoprzedstawiające?" ${ }^{\prime 8}$. W badanej twórczości można wyodrębnić killka rodzajów emigracji i dla każdego z nich charakterystyczne typy bohaterek:

a) Emigracja kulturowa. Narrację na jej temat tworzy najczęściej bohaterka z wykształceniem wyższym, w wieku 25-30 lat, dobrze znająca język angielski, singielka. Jej status społeczny jest wysoki, wykonuje pracę zgodną z wykształceniem. Bohaterka chciała zamieszkać w kraju wielokulturowym, tolerancyjnym, świeckim ${ }^{87}$ : , jestem emigrantką intelektualną. Nie jestem

84 A.M. Bakalar Madame Mephisto.

85 O pisaniu i pieniqqdzach. Z poetkg Wiolettq Grzegorzewskq rozmawia Urszula Chowaniec , ZZadra” $2013 \mathrm{nr} 1-2(54-55)$, s. 53.

S. Smith, J. Watson Wprowadzenie..., s. 87.

87 Zob. A.M. Bakalar Madame Mephisto; A. Martynowska Przebojowa Polka w Londynie; A. Kwiatkowska Dzwonki owiec i duch Wiliama Wallace'a; K. Latała W krainie wietrznych deszczowców; M. ZaraskaZawieszeni; M. Budacz Wot4, Papierowy Motyl, Warszawa 2013. 
w stanie mieszkać w Polsce" ${ }^{\text {88 }}$. Odmianą emigracji kulturowej jest emigracja naukowa - np. studia doktoranckie ${ }^{89}$. Czy nie jest to bardziej mobilność zawodowa niż emigracja? Ta grupa dys ponuje najwyższym kapitałem społecznym i kulturowym. Podobne reprezentacje bohaterek literackich utrwaliły Polki-emigrantki w latach 9o. XX wieku0.

b) Emigracja kulturowo-zarobkowa. To najczęstszy rodzaj emigracji i najbardziej popularny typ bohaterki - kobieta z wykształceniem średnim lub wyższym w wieku 20-30 lat, pochodząca często ze wsi lub małego miasteczka i bez dobrej znajomości języka angielskiego, singielka. Zaczyna w „zawodowym getcie płci" (jako sprzątaczka, opiekunka, niania, służąca). Podnosi kwalifikacje i powoli awansuje społecznie ${ }^{91}$. W twórczości tej spotykają się dwie narracje: liberalna oraz wrażliwa społecznie, która obnaża mechanizmy dyskryminacji kobiet.

Do końca lat 8o. XX wieku w tradycji literackiej utrwaliły się dwa rodzaje emigracji: polityczna i zarobkowa. Od lat 9o. XX wieku pojawił się nowy rodzaj - który Przemysław Czapliński nazwał migracją egzystencjalną ${ }^{92}$. Autorki określają emigrację jako: kulturową, naukową, obyczajowo-społeczną, rozwojową, intelektualną, a nawet cywilizacyjną. Uważam, że można ją także określić szerokim terminem migracji egzystencjalnych.

c) Emigracja zarobkowa. Bohaterka to Polka w średnim wieku, która w kraju zostawiła dzieci i męża. Decyzja o emigracji wynika z bezrobocia i zagrożenia ubóstwem. Grupa ta ma najniższy kapitał społeczny i kulturowy, a emigracja zarobkowa utrwala ich niską pozycję, ponieważ zmusza do powtarzania tradycyjnych ról płciowych (sprzątanie, opieka nad dziećmi i osobami zależnymi). W tego rodzaju narracjach czasem następuje przejście od emigracji zarobkowej ku kulturowej/rozwojowej/emancypującej ${ }^{93}$.

88 Profesionalna kłamczucha, s. 31.

89 K. Malanowska Imigracje.

90 Np. Manuela Gretkowska, Natasza Goerke, Izabela Filipiak, Brygida Helbig-Mischewski. Zob. A. Mrozik, B. Karwowska Oswajanie samotności. Kobiecy dyskurs imigracyiny "drugiego świata" w polskiejperspektywie " Przegląd Humanistyczny" $2008 \mathrm{nr}$ 5, S. 119-132.

91 Zob. Emigrantka z wyboru, Opowieść emigracyina, Dublin, Wyfrunęli, Moja podróż przez życie, M. Semeniuk Emigrantkq być, czyli wspomnienia z Wells, Warszawska Firma Wydawnicza, Warszawa 2011; Pensionat na wrzosowisku, Irlandzki koktajl, Oddaleni.

P. Czapliński Konturymobilności, w: Poetyka migracji. Doświadczenie granic w literaturze polskiej przełomu XXiXXI wieku, Wydawnictwo UŚ, Katowice 2013.

93 Zob. twórczość Dany Parys-White, Łucji Fice, Alicji Szafran i Marty Semeniuk. 


\section{Podsumowanie: potencjał transgresyjny i rewindykacyjny twórczości emi- grantek}

W tym artykule starałam się scharakteryzować najnowszą twórczość emigracyjną kobiet, co nie jest zadaniem łatwym z uwagi na obszerność i róźnorodność materiału. Kluczowe pozostaje jednak to, co ją spaja - a są to strategie odzyskiwania ciała i głosu:

1. Upublicznienie i zarazem upolitycznienie sytuacji kobiet w Polsce i na emigracji - przez ukazanie rodzajów władzy i presji (ekonomicznej, kulturowej, religijnej i obyczajowej), którym podlegają kobiece podmioty;

2. Rekonstruowanie matrylinearnego dziedzictwa, rodzinnych i społecznych więzi między kobietami, przyjaźni, sojuszy i współpracy międzypokoleniowej kobiet;

3. Rekonstruowanie alternatywnej narodowej tożsamości Polki;

4. Upublicznienie traum i nadużyć, zapisanych w ciałach kobiet i skrywanych dotąd w jednostkowej, wspólnotowej i biochemicznej pamięci;

5. Wyrażenie własnego, jednostkowego doświadczenia emigracji. To zbiór głosów kobiet, różniących się wykształceniem, pochodzeniem, wiekiem, klasą społeczną. Ta wielogłosowość pozwala analizować uwarunkowania: rodzinne, społeczne, religijne, narodowe, które kształtują kobiece podmioty. Tym samym twórczość ta wypełnia wiele białych plam w krajowej literaturze kobiet.

Autorki najnowszej twórczości emigracyjnej są świadome dyskryminacyjnych mechanizmów społecznych, którym podlegają podmioty kobiece, zarówno w kraju, jak i na emigracji. Dlatego piszą także o tym, że niska pozycja społeczna emigrantek stwarza okazje do wyzysku, łamania praw, naraża kobiety na nadużycia seksualne. Jednocześnie pisarki starają się odnaleźć na rynku wydawniczym, więc swoje opowieści formatują jako literaturę rozrywkową, nierzadko w konwencji romansu. Stwarza to szansę na wzbogacenie nurtu polskiej literatury rozrywkowej o wrażliwość społeczną i kluczowe dla kobiet kwestie. Daje także nadzieję na to, że takie tematy jak polskość, tradycja, naród, religia, tożsamość - będą dalej redefiniowane krytycznie z perspektywy kobiet:

rewindykacja norm w literaturze kobiet często łączy się ze swoistym ruchem nomadycznym, włóczęgowskim. Ten, kto widział coś innego (podróżniczka, włóczęga, banitka, emigrantka), może postrzegać świat w odmiennym świetle. Stąd też popularność turystek, podróżniczek, włóczęg 
(włóczęgiń) w najnowszej literaturze. Oglądają świat, a on coraz mniej im się podoba ${ }^{94}$.

\section{Abstract}

\section{Anna Kronenberg}

UNIVERSITY OF ŁÓDŹ

Women's Migrations: Strategies of Regaining One's Voice and Body in Literary Works by Polish Women in the UK and Ireland

Kronenberg examines literary works by Polish women in the UK and Ireland after 2004 Her critical perspective highlights the cultural, broadly socio-political context, including the question of gender, as modelled by Inga Iwasiów, Maria Janion, Agnieszka Mrozik Przemysław Czapliński and Ursula Chowaniec; Kronenberg also draws on studies on subjectivity in women's autobiographical practices by Sidonie Smith, Julia Watson and others. She presents emigre women writers' strategies of regaining their voice and body by isolating the characteristic traits of this type of writing, such as social engagement, awareness of discriminatory mechanisms, or the potential for transgression and revendication.

\section{Keywords}

emigre women's writing, women's autobiographical practices, migration, feminist criticism

94 U. Chowaniec, Smutek jest podszewka świata, s. 90 . 